\title{
PREVALENCE OF SHISHA-AIDED FLAVOURED TOBACCO SMOKING AMONG STUDENTS IN PUBLIC UNIVERSITIES IN RIVERS STATE, NIGERIA
}

\author{
Jones, Gloria Stanley Acra ${ }^{1}$, \\ J. E. F. Okpako ${ }^{2 i}$ \\ ${ }_{1}^{1}$ Post Graduate School, \\ Department of Human Kinetics \\ and Health Education, \\ Faculty of Education, \\ University of Port Harcourt, \\ Nigeria \\ 2Prof., Department of Human Kinetics \\ and Health Education, \\ Faculty of Education, \\ University of Port Harcourt, \\ Nigeria
}

\begin{abstract}
:
The study investigated the prevalence of shisha-aided flavoured tobacco smoking among students in public universities in Rivers State. The study emphasized on the number of students associated with shisha use in the three public universities located in Rivers State. It is a cross-sectional study carried out among undergraduate students in public universities in Rivers State with population forty seven thousand, five hundred and seventeen $(47,517)$ from the three (3) public universities in Rivers State, using a sample size of one thousand undergraduate students drawn through a multi-stage sampling procedure. The instrument used for data collection were 30 items structured questionnaire titled "Prevalence of Shisha-aided Flavoured Tobacco Smoking (PSFTS)" which has a reliability coefficient of 0.91 and focus group discussion. Data was analyzed using frequency and percentage for the demographic characteristics, while mean and standard deviation was used to answer the research question. While ANOVA was used to test the hypotheses at .05 alpha level of significance. The findings of the study revealed that the prevalence of shisha-aided that the prevalence of shisha-aided flavoured tobacco smoking was considerably low. The study concluded with the following recommendations that health awareness campaign/trainings among students on health risks implications and on admission of students, during orientation the universities authorities should marshal modalities to halt the use of shisha and all other forms of tobacco use.
\end{abstract}

i Correspondence: email glostan545@gmail.com, okpakojef@gmail.com 
Keywords: visual impairment, social inclusion, special needs counselling guidelines, counselling implications

\section{Introduction}

Shisha-aided flavoured tobacco smoking is a growing health concern globally, and is on the increase among young people worldwide, even though is common among all age groups.

Shisha is an instrument or device used in smoking flavoured tobacco and is still emerging with evidence that it poses health risks (Taylor Hays, 2017). It is also believed that some toxins in the smoke inhaled are filtered out by the water in the pipe, therefore it is less harmful (Maziak et al., 2004). It is revealed shisha as is associated with increased heart rate, high blood pressure, impaired pulmonary function, chronic bronchitis, and emphysema and coronary artery disease as a result of prolong use, even periodontal diseases, lung and esophageal cancer is also traced to shisha use (Qasim, Alarabi, Alzoubi, Karim, Alshbool and Khasawneh, 2019).

Globally is recorded that tobacco use result to more than seven million people using it annually and this figure may likely rise to eight million death every year by 2030 (World Health Organisation, 2013). About six million of health are due to direct tobacco use and 890,000 are due to exposure to second-hand smoke.

Generally, tobacco smoking can be prevented, but recently a new device popularly called shisha or hookah is used to smoke flavoured tobacco in various forms and its gaining popularity because of its attracting flavours (Kiran, Bhikhu and Milesh, 2015). Shisha's use actually began in the eastern Mediterranean area and is gradually picking up prevalence in the Western Nations like Australia, United Kingdom, Canada and the United States of America including South-east, Asia.

\section{Statement of the Problem}

Shisha-aided flavoured tobacco smoking is an emerging problem with evidence that it poses health problems shisha-users believes that some toxins contained in the smoke inhaled are filtered out by the water in the pipe, therefore it is less harmful. Globally shisha use has been associated with negative impact that can be related to increase mortality and mortality rate. Nigeria is not exception as the trend of shisha use constitute threat to life, it was on this note that the Minister of Health on the $5^{\text {th }}$ June 2018 banned the sale and smoking of shisha-aided flavours tobacco in public places in Nigeria. In Rivers State it was observed that student in tertiary institutions indulge in the use of shisha. It is view of this that the researcher investigated the prevalence of shisha-aided flavoured tobacco smoking in public universities in Rivers State. 


\subsection{Research Question}

To guide this study this research question below was posed:

1) What is the prevalence of shisha-aided flavoured tobacco smoking among students in public universities in Rivers State based on gender?

\subsection{Hypothesis}

There is no significant difference in prevalence of shisha flavoured tobacco smoking among students in public universities in Rivers state based on gender.

\section{Methodology}

A cross-sectional descriptive research survey design was adopted for the study. The population comprised all the undergraduates' students in three public universities in Rivers State. A sample size of one thousand $(1,000)$ undergraduate students was using multi-stage sampling procedure, $50 \%$ of the number of Faculties.

A self-structured questionnaire titled "Prevalence of Shisha-Aided Flavoured Tobacco Smoking (PSFTS)" was used to collect data for the study. The questionnaire had two sections: Section A was used to collect the demographic data, while Section B was used to collect answers to the research variables. Instrument was validated by subjecting it to the scrutiny of five (5) experts in the Department of Human Kinetics and Health education, Faculty of Education, University of Port Harcourt for face and content validity. Their inputs ensured that the instrument was valid enough for the study. The test-retest method was used to determine the reliability of the instruments. It yielded an index of 0.91 using Pearson Product Moment Correlation Coefficient. Hypothesis was tested using ANOVA at .05 level of significance.

\section{Results and Discussion}

Table 1: Distribution of the Gender of the Respondents

\begin{tabular}{|l|c|c|c|}
\hline Gender & Frequency & Percent & Remark \\
\hline Male & 440 & 45.4 & \\
\hline Female & 530 & 54.6 & $*$ \\
\hline Total & 970 & 100.0 & \\
\hline
\end{tabular}

${ }^{*}$ Dominant

Table 1 shows the distribution of the gender of the respondents. It shows that 530 representing $(54.6 \%)$ of the female students participated in the study while 440 representing $(45.4 \%)$ of the participants were male students.

Research Question 1: What is the prevalence of Shisha-aided flavoured tobacco smoking among students in Public Universities in Rivers State based on Gender? 
Table 2: Mean rating of the prevalence of Shisha-aided flavoured tobacco smoking among students in Public Universities in Rivers State based on Gender

\begin{tabular}{|c|l|c|c|c|c|}
\hline \multirow{2}{*}{ SN } & \multirow{2}{*}{ Prevalence } & \multicolumn{2}{c|}{ Male, $\mathbf{n}=\mathbf{4 4 0}$} & \multicolumn{2}{c|}{ Female, $\mathbf{n = 5 3 0}$} \\
\cline { 3 - 6 } & Mean & SD & Mean & SD \\
\hline 5 & $\begin{array}{l}\text { I smoke flavoured tobacco with the aid of a device } \\
\text { called Shisha-aided flavoured tobacco smoking/hookah. }\end{array}$ & 1.99 & 1.10 & 1.61 & 1.01 \\
\hline 6 & $\begin{array}{l}\text { I smoke Shisha-aided flavoured tobacco smoking } \\
\text { in the past and I no longer smoke now. }\end{array}$ & 1.88 & 1.01 & 1.57 & 0.97 \\
\hline 7 & $\begin{array}{l}\text { I used Shisha-aided flavoured tobacco smoking } \\
\text { in the past. }\end{array}$ & 2.00 & 1.10 & 1.58 & 0.97 \\
\hline 8 & I enjoy smoking flavour tobacco. & 1.82 & 1.08 & 1.47 & 0.91 \\
\hline 9 & I presently smoke flavoured tobacco. & 1.91 & 1.09 & 1.48 & 0.89 \\
\hline 10 & $\begin{array}{l}\text { Shisha-aided flavoured tobacco smoking gives } \\
\text { me pleasure. }\end{array}$ & 1.78 & 1.05 & 1.49 & 1.49 \\
\hline & Grand mean & $\mathbf{1 . 9 0}$ & $\mathbf{0 . 9 4}$ & $\mathbf{1 . 5 4}$ & $\mathbf{0 . 8 6}$ \\
\hline
\end{tabular}

The result on Table 2 shows the mean rating of the prevalence of Shisha-aided flavoured tobacco smoking among students in Public Universities in Rivers State based on Gender. It shows the mean rating of the respondents over prevalence of Shisha-aided flavoured tobacco smoking in Public Universities in Rivers State was generally low. Specifically, participants of male gender had mean rating of $1.90, \mathrm{SD}=0.94$ whereas the female had mean rating of $1.54, \mathrm{SD}=0.86$.

$\mathbf{H}_{01}$ : There is no significant difference in the prevalence of Shisha-aided flavoured tobacco smoking among students in Public Universities in Rivers state based on gender.

Table 3: Summary of factorial design ANOVA on the difference in the prevalence of Shisha-aided flavoured tobacco smoking among students in Public Universities in Rivers State based on gender

\begin{tabular}{|l|l|c|c|c|c|c|}
\hline Demographics & Source & Sum of Squares & df & Mean Square & F & Sig. \\
\hline Gender & Between Groups & 31.638 & 1 & 31.638 & 39.483 & .000 \\
\hline & Within Groups & 775.679 & 968 & .801 & & \\
\hline & Total & 807.317 & 969 & & & \\
\hline
\end{tabular}

The result on Table 3 shows the summary of one-way ANOVA on the difference in the prevalence of Shisha-aided flavoured tobacco smoking among students in Public Universities in Rivers state based on Gender of study. It shows that (F1, 969=39.48, p<.05) had no significant influence on the prevalence of Shisha-aided flavoured tobacco smoking among students in Public Universities in Rivers State. The null hypothesis one was rejected at .05 level of significance.

\section{Discussions}

Prevalence of the health risks associated with Shisha-aided flavoured tobacco smoking among students in Public Universities in Rivers State. 
The findings on Table 1 established that the respondents 530 representing (54.6\%) of the female student participated in the study, while 440 representing $(45.4 \%)$ of the participants were male students.

Table 2 shows the mean rating of the prevalence of shisha-aided flavoured tobacco smoking among students in public Universities in Rivers State based on gender shows the mean rating of the respondents over prevalence of shisha-aided flavoured tobacco smoking in public universities in Rivers State was generally low, specifically, participants of male gender had mean rating of $1.90, \mathrm{SD}=0.94$ whereas the female had mean rating of $1.54, \mathrm{SD}=0.86$. This finding is consistent with an earlier finding by Bankole, Victor and Helena (2018) which states that prevalence rate of tobacco smoking ranged from $0.2 \%$ to $32.5 \%$. Among the gender-specific studies the prevalence of smoking among females ranges between $2.2 \%$ to $10 \%$ while males ranged from $1 \%$ to $32.5 \%$. Smoking prevalence was higher among males than females.

\section{Conclusion}

Based on the finding prevalence of shisha-aided flavoured tobacco smoking is low, hence concentrated efforts to target the students both in school and out-of-school control strategies becomes very important and implementation of laws guiding shisha use in the society. Both students and parent should be counsel on the huge effect of shisha use on health.

\subsection{Recommendations}

Based on the finding, it can be recommended that:

1) Counseling, helping and isolation centres should be provided for those who are ready to quit the act of shisha use.

2) The sales and smoking of any form of tobacco including shisha use should be prohibited in the universities' campuses.

3) Since the study revealed that the prevalence of shisha use is low, the university communities should counsel new students during every orientation programme during new intake to eschew all of forms of tobacco smoking.

4) Regular health awareness campaigns on the effects of shisha use on health.

\section{Conflict of Interest Statement}

The authors declare no conflicts of interests.

\section{About the Authors}

Jones, Gloria Stanley Acra is a Postgraduate Student, Department of Human Kinetics and Health Education, Faculty of Education, University of Port Harcourt, Nigeria. Education qualifications: B.SC, MSC, PhD in view. email: glostan545@gmail.com.

J. E. F. Okpako is Professor in Department of Human kinetics and Health Education Faculty of Education, University of Port Harcourt, Nigeria. email: okpakojef@gmail.com 


\section{References}

Administrative Offices of the Institutions 2018/2019, Nigerian Universities Commission Brochure.

Aslam, H. M., Saleem, S., German, S. \& Qureshi, W. A. (2014). Harmful effects of Shishaaided flavoured tobacco smoking: literature review. Int. Arch Med. 7(16).

Bankole, K., O., Victor, J., A., \& Helena (2018). Tobacco use in Nigeria youth: a systematic review. Plos ONE 13(5).

Fakhreddine H. M., Kanj A. N. (2019). The effects of hookah, waterpipe smoking on general Health and the cardiovascular system Environmental health and preventive medicine 24 (1) 1-17, 2019.

Helmy, H. M., Farizah, M. H., Fatihad, M. A. \& Amer, A. N. (2015). Shisha-aided flavoured tobacco smoking: knowledge and prevalence among high school students. European Respiratory Journal, 46:4135.

Jukema, J. B., Bagnasco, D. E. \& Jukema, R. A. (2014). Waterpipe smoking: Not necessarily less hazardous than cigarette smoking. Neth. Heart J., 22, 9 1-99.

Kadhum, M., Sweidan, A., Jaffery, A. E., Al-Saadi, A. \& Madden, B. (2015). A review of the health effects of smoking Shisha-aided flavoured tobacco smoking. Clinical Medical. 15, 263-266.

Kandela, P. (2000). Narghile smoking keeps Arabs in wonderland. Lancet, 356, 1175.

Kehinde, K. K., Faruk, A. M., Nyideka, J. N., Omotayo, F. F., Miracle, A. A., Bashar, M. A. and Precious, A. O. (2019). Poor knowledge of the Harmful Effects of shisha smokers: Findings from a preliminary survey in Northwest Nigeria. Medical University Journal Vol.2 Issue 2 Doi; https//doi.org/10.2478/medu-2019.

Kiran, R., Bhikhu, J. M. \& Nileshi, C. T. (2015). Knowledge, attitude and practices of hookah smoking among medical students in Gujarat, India. A cross sectional study international Journal of advances in medicine 2(4) 397-400.

Maziak, W., Eissenberg, T., Rastam, S., Hammal, F., Asfar, T., Bachir, M.E., Fouad, M.F., Ward, K. D. (2004). Beliefs and attitudes related to narghule (waterpipe) smoking among university students in Syria. Ann. Epidemiol., 14, 646-654.

Qasim, H., Alarabi, A. B., Alzoubi, K. H., Karim, Z. A. Alshbool, F. Z. and Khasawneh F. T. (2019). The effect of hookah/waterpipe smoking on general health and cardiovascular system. Environ Health Prev med 24 ;58 (2019) https://doi.org/10.1186/512199-019-0811-y.

Taylor-Hays, J. (2017). Ts hookah smoking safer than smoking cigarettes? Free Mayo Clinic enewsletter. https://www.mayoclinic.org/healthy lifestyle/quit-smoking/expertanswers/hookah/faq-20057920.

Wong Li, Alias, H., Aghamohammadi, N., Aghazadeh, S. \& Chee Wai, V. (2016). Shisha smoking practices, use reasons, attitudes, health effects and intentions to quit among shisha smokers in Malaysia. Int. J. Environ Res Public Health. 2016 Jul: 13(7): 726 doi:10.3390/ijerph13070726 PMCID:PMC 4962267. 
World Health Organization (WHO) (2013). News Minister of Health: Retrieved from: https://afro.who.institute.

World Health Organization (WHO) (2008). Tobacco and heart disease. Retrieved from: https://www.who.Int. 
Jones, Gloria Stanley Acra, J. E. F. Okpako

PREVALENCE OF SHISHA-AIDED FLAVOURED TOBACCO SMOKING

AMONG STUDENTS IN PUBLIC UNIVERSITIES IN RIVERS STATE, NIGERIA

Creative Commons licensing terms

Author(s) will retain the copyright of their published articles agreeing that a Creative Commons Attribution 4.0 International License (CC BY 4.0) terms will be applied to their work. Under the terms of this license, no permission is required from the author(s) or publisher for members of the community to copy, distribute, transmit or adapt the article content, providing a proper, prominent and unambiguous attribution to the authors in a manner that makes clear that the materials are being reused under permission of a Creative Commons License. Views, opinions and conclusions expressed in this research article are views, opinions and conclusions of the author(s). Open Access Publishing Group and European Journal of Public Health Studies shall not be responsible or answerable for any loss, damage or liability caused in relation to/arising out of conflicts of interest, copyright violations and inappropriate or inaccurate use of any kind content related or integrated into the research work. All the published works are meeting the Open Access Publishing requirements and can be freely accessed, shared, modified, distributed and used in educational, commercial and non-commercial purposes under a Creative Commons Attribution 4.0 International License (CC BY 4.0). 